\title{
RELATIONSHIP BETWEEN ENERGY CONSUMPTION AND ECONOMIC GROWTH IN 30 COUNTRIES IN EUROPE - PANEL
}

In this paper, we study the link between energy consumption and economic growth for the thirty surveyed countries in Europe. Although there are many articles on this topic, the difference between them and this one is that we study countries that have not yet been studied together. The variable that is used for consumption is the final energy consumption, which includes the consumption of all forms of energy. In this paper, we use panel data analysis that studies the connections based on the methods of fixed effect. The data used were collected from European databases, Eurostat. Based on the results of the panel data regression, we can conclude that there is a strong correlation between the observed variables. What is needed for further research is to study the correlation between variables in the long and short-term. Equally interesting would be to study the way of integration with countries that have their power sources and those that do not.

Keywords: energy consumption, panel data regression, fixed effect, GDP.

* S. Stjepanović, Ph.D., Assistant Professor, Faculty of Economics and Tourism „Dr. Mijo Mirković“, Juraj Dobrila University of Pula (E-mail: sstjepan@unipu.hr). 2018.

The paper was received on April 18th, 2017. It was accepted for publication on January 17th,

This work has been fully supported by the Croatian Science Foundation under the project number 9481 Modelling Economic Growth - Advanced Sequencing and Forecasting Algorithm. 


\section{Introduction}

In recent years, there has been a very large number of papers which study the correlation between economic growth and energy consumption. However, there is a very significant difference between the results obtained in these different papers. That is because all these papers are made in various techniques, with different approaches and different procedures in the analysis. The main hypothesis of this paper is to establish the link between energy consumption and economic growth for all countries in Europe. We will use all the countries in Europe regardless of their development or energy independence. Although there are many types of research on this topic, there is no research that covers all the countries in Europe that have available statistical data. The main issue of this paper is to study the link between the final energy consumption and economic growth. We assume correlation of economic growth with energy consumption. However, it is necessary to determine the direction of this association, which is not always clearly defined. What is not certain is the time when the state increased power consumption, which resulted in an increased economic growth and to what extent is it a reference to the increase. The central question posed in this paper is crucial because it reveals how much is necessary to increase the power consumption that would occur as a change in the economic growth. We show the link between economic growth and the final energy consumption in 30 countries in Europe. In this paper, the data were collected for the observed countries for final energy consumption, which is made up of energy consumption arising from solid fuels, oil, gas, nuclear power, heat, renewable energy sources, and waste. With this information, we observe gross domestic product expressed in market prices. Using panel data analysis, we will analyze the relationship between the variables in thirty countries in Europe. The observed countries are members of the European Union, and we also used several States that are significant to the analysis but are not members of EU.

There are a very large number of studies dealing with this analysis. One of the many papers on this topic is the work of Kasperowicz (2014), entitled "Economic growth and energy consumption in 12 European countries: a panel data approach". This paper studies the link between energy consumption and economic growth in 12 countries of the European Union in 13 years. The hypothesis of this article, which was later confirmed, is that there is a positive correlation between energy consumption and economic growth. The evaluated regression model includes growth rates of energy consumption and growth rates of gross fixed capital at real prices. The analysis states that energy consumption is not neutral to economic growth in the analyzed countries.

The following work written on this subject is by Ucan and others (2014), Energy consumption and economic growth nexus: Evidence from developed countries in Europe. This paper analyzes the relationship between the use of renewable 
and non-renewable energy sources and economic growth for 15 countries of the European Union over a period of 22 years. The cointegration test panel shows a long-term equilibrium correlation between real GDP and consumption of energy from renewable and non-renewable sources. Belke and others (2011) studied the long-term correlation between energy consumption and real GDP, including energy prices. This paper outlined the use of methods of studying individual components which allow the study of the international and national impact on long-term growth.

With similar topic, Hu et al. (2015) studied the connection between energy consumption and economic growth in the case of industrial sectors in China. This paper used panel data observed for 37 different industry sectors in China. The paper concludes that in the short term there is a one-way influence of economic growth on energy consumption, while in the long term there is a unidirectional impact of energy consumption on economic growth. Bildirici (2014), in his work, explains the co-integration link between the consumption of energy derived from biomass and economic growth in transition countries. In this case, they are looking at the consumption of biomass as a substitute for energy derived from oil and other fossil fuels. The study confirmed a positive association between the consumption of energy derived from biomass and economic growth. Yang (2012) studies the link between energy consumption and economic growth in China. China, in an effort to turn to the sustainable green economy, attempts at reducing energy consumption in order to reduce environmental pollution and thus increase its sustainable GDP. The question that arises in this work is whether the reduction of the energy consumption has an impact on economic growth and to what extent. The result of the work shows a link between economic growth and energy consumption. Dedeoglu and others (2014) study the connection between economic growth and energy consumption in the former Soviet countries for ten years. The authors conclude that in the short term there is no connection between these two variables, while in the long run there is a connection. Heiko (2012) studied neutrality hypothesis between energy consumption and economic activity in the EU countries. What this work shows is that in developed old EU Member States the event of the reduction of energy consumption leads to an increase in economic growth, while in the new EU member states they came to the opposite conclusion, meaning that an increase in energy consumption leads to the growth of economic activity.

\section{Data}

The data used in this study were obtained from the database of Eurostat, which is the statistical office that collects data for the European Union. Data that we use in this paper are obtained for this countries: European Union (28 coun- 
tries), Euro area (19 countries), Belgium, Bulgaria, Czech Republic, Denmark, Germany, Estonia, Ireland, Greece, Spain, France, Croatia, Italy, Cyprus, Latvia, Lithuania, Luxembourg, Hungary, Malta, Netherlands, Austria, Poland, Portugal, Romania, Russia, Slovenia, Slovakia, Finland, Sweden, United Kingdom, Iceland and Norway. We use a different type of countries that are developed and underdeveloped, that are in transition, that they have own energy production and those that depend on other countries in energy production. We use this different country to enrich our paper. The observed period is from 1994 to 2016., on a yearly basis. We look at two variables, the Gross Domestic Product at market prices and Final energy consumption in tons of oil equivalent. The data were collected for thirty-one countries, involving the European Union countries and countries which are in Europe, and whose energy consumption and energy production are distinct and interesting for this work. The paper intended to involve as many countries as possible, which are in Europe, in the model we are going to observe, but there is a problem that less developed countries do not have statistics on energy consumption. That is why they have not been considered. For GDP, we took data on GDP in all the countries observed at market prices. Total energy consumption is taken for the energy consumption variable, which is obtained by summing the energy consumption of all available energy sources, expressed in equivalent tons of oil. We observed countries that are developed and long-lasting states of the European Union or the transition countries that are less developed and subsequently became members of the European Union. On this basis, we can see that there will be differences in the impact of energy consumption on the economic growth between developed and less developed countries.

Table 1.

\section{DESCRIPTIVE STATISTICS}

\begin{tabular}{|l|c|c|c|c|c|}
\hline Variable & Obs & Mean & Std. Dev. & Min & Max \\
\hline gdp & 640 & 954165.1 & 2392105 & 2829 & $1.40 \mathrm{e}+07$ \\
\hline ene & 640 & 96864.68 & 235392.9 & 364.8 & 1192622 \\
\hline
\end{tabular}

Source: Author's calculation.

Variable gdp represents the GDP at market prices, and variable ene represents the final energy consumption. From Table 1 we can see, we have 640 observations, that there is a big difference between the minimum and maximum observed variables, which tells us that we have a great diversity of countries that we include in this paper. 


\section{Empirical results}

In this paper, we use a panel model with fixed-effect. We use the fixed-effect when we want to analyze the influence of variables that vary over time. FE studies the relationship between the predictor and the output variables within a single unit (country, person, company, etc.). Each unit has its characteristics that may or may not affect predictor variable (for example, being male or female can affect the answers given during questioning). When we use the FE or Fixed-effect method, we assume that the individual characteristics may influence the assessment of the predictor variables and output. FE method eliminates these time characteristics of the individual and thus gives us the effective net access to the dependent and independent variables. Another important assumption is that the FE model and the individual time characteristics of the individual are private and can not be brought into connection with other characteristics of other individuals. If these features are correlated to each other in this case, the FE model is not suitable for use.

The equation for the fixed effect model is:

$$
Y_{i t}=\beta_{1} X_{i t}+\alpha_{i}+u_{i t}
$$

Where:

- $\alpha_{i}(i=1 \ldots n)$ is the unknown intercept for each entity (n entity-specific intercepts)

- $Y_{i t}$ is the dependent variable (DV) where $\mathrm{i}=$ entity and $\mathrm{t}=$ time.

- $\mathrm{X}_{i t}$ represents one independent variable (IV),

- $\beta_{1}$ is the coefficient for that IV,

- $u_{i t}$ is the error term.

The key insight is that if the unobserved variable does not change over time, then any variations in the dependent variable must be due to influences other than these fixed characteristics. Another way to see the fixed effects model is by using binary variables. So the equation for fixed effects model becomes:

$$
Y_{i t}=\beta_{0}+\beta_{1} X_{1, i t}+\ldots+\beta_{K} X_{K, i t}+Y_{2} E_{2}+\ldots+Y_{n} E_{n}+u_{i t}
$$

Where:

- $Y_{i t}$ is the dependent variable (DV) where $\mathrm{i}=$ entity and $\mathrm{t}=$ time.

- $X_{k, i t}$ represents one independent variable (IV), 
- $\beta_{k}$ is the coefficient for that IVs,

- $u_{i t}$ is the error term.

- $E_{n}$ is the entity n. Since they are binary (dummies) you have n- 1 entities included in the model.

- $Y_{2}$ is the coefficient for the binary repressors (entities).

Table 2.

\section{OLS REGRESSION}

\begin{tabular}{r|rrr} 
Source & SS & df & MS \\
\hline Model & $3.5091 \mathrm{e}+15$ & 1 & $3.5091 \mathrm{e}+15$ \\
Residual & $1.4732 \mathrm{e}+14$ & 638 & $2.3092 \mathrm{e}+11$ \\
\hline Total & $3.6565 \mathrm{e}+15$ & 639 & $5.7222 \mathrm{e}+12$
\end{tabular}

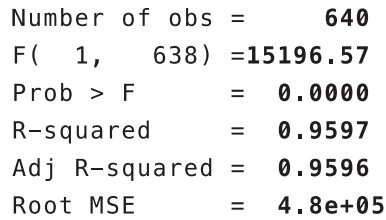

\begin{tabular}{r|rrrrrr}
\hline gdp & Coef. & Std. Err. & $t$ & $P>|t|$ & [95\% Conf. Interval] \\
\hline ene & 9.95535 & .0807577 & 123.27 & 0.000 & 9.796767 & 10.11393 \\
_cons & -10156.69 & 20542.63 & -0.49 & 0.621 & -50496.04 & 30182.66 \\
\hline
\end{tabular}

Source: Author's calculation.

OLS regression shows that the p-value is zero, which means that we can accept the hypothesis that all coefficients are different from zero. From this, we see that we cannot use ordinary OLS regression, but we have to apply a panel data with fixed effects or random effects. Using the Hausman test, the result of this test has shown us the obligation of using fixed effects methods in the panel. 
Table 3.

\section{PANEL DATA REGRESSION WITH FIXED EFFECTS}

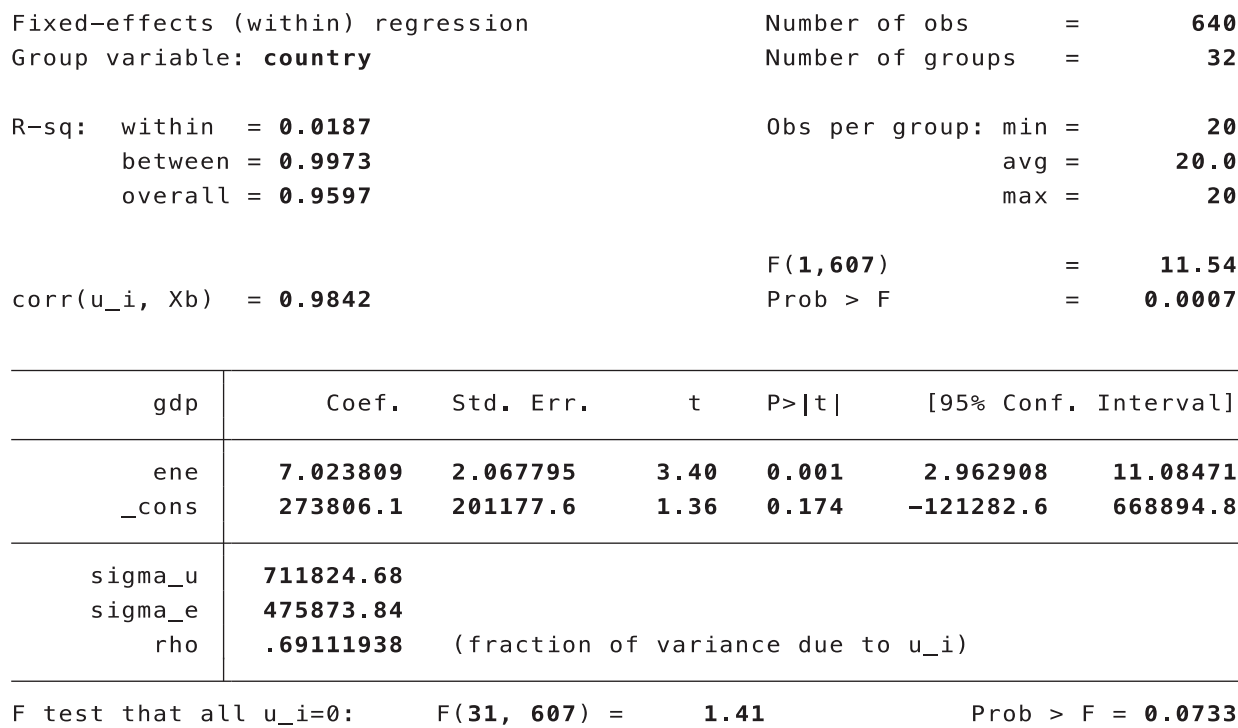

Source: Author's calculation.

From Table 3 we see that the coefficient of 7.023 is for the ene variable, which indicates that if the energy consumption is changed by one unit to the observed variable GDP would change for 7.023 units. If we consider the t-value, we can see that it is greater than 1.96 , with which we conclude that the variable energy consumption has a significant influence on the observed variable GDP. From the F-test, we can see that all the coefficients in the model are different from zero. P-test confirms the same as the t-test or the substantial significance of the ene variable on the observed variable. Using Breusch-Pagan LM test for cross-sectional dependence correlation we conclude that we have no cross-sectional dependence. After testing heteroscedasticity, we concluded that there is no presence of heteroskedasticity in the model.

In the following tables, we have calculated the impact of energy consumption on GDP in underdeveloped countries or transition countries and developed countries. 
Table 4.

\section{PANEL DATA REGRESSION WITH FIXED EFFECTS - COUNTRIES IN TRANSITION AND UNDERDEVELOPED COUNTRIES}

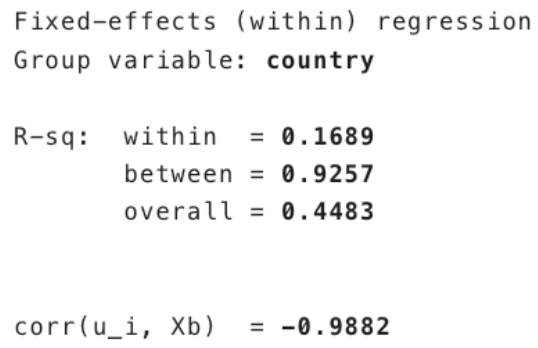

\begin{tabular}{r|rrrrrr}
\hline gdp & Coef. & Std. Err. & t & P $>|t|$ & [95\% Conf. Interval] \\
\hline ene & $\mathbf{8 . 9 5 6 0 2}$ & $\mathbf{1 . 6 1 6 5 8 6}$ & $\mathbf{5 . 5 4}$ & $\mathbf{0 . 0 0 0}$ & $\mathbf{1 2 . 1 5 0 0 7}$ & $\mathbf{5 . 7 6 1 9 7 2}$ \\
_cons & 108134.2 & 13731.75 & $\mathbf{7 . 8 7}$ & $\mathbf{0 . 0 0 0}$ & $\mathbf{8 1 0 0 3 . 0 1}$ & $\mathbf{1 3 5 2 6 5 . 4}$ \\
\hline sigma_u & $\mathbf{8 5 2 8 1 . 3 3 4}$ & & & & & \\
sigma_e & 18265.277 & & & & & \\
rho & .95614025 & (fraction of variance due to u_i) & \\
\hline
\end{tabular}

F test that all $u_{-} i=0: \quad F(7,151)=10.21 \quad$ Prob $>F=0.0000$

Source: Author's calculation.

In table 4, we have used all countries in transition like Croatia, Romania, Bulgaria, Estonia, Latvia, Lithuania, Slovenia, and Slovakia. From Table 4 we see that the coefficient of 8.956 is for the ene variable, which indicates that if the energy consumption is changed by one unit to the observed variable GDP would change for 8.956 units. If we consider the t-value, we can see that it is greater than 1.96, with which we conclude that the variable energy consumption has a significant influence on the observed variable GDP. From the F-test, we can see that all the coefficients in the model are different from zero. P-test confirms the same as the t-test or the substantial significance of the ene variable on the observed variable. Using Breusch-Pagan LM test for cross-sectional dependence correlation we conclude that we have no cross-sectional dependence. After testing heteroscedasticity, we concluded that there is no presence of heteroskedasticity in the model. 
Table 5.

\section{PANEL DATA REGRESSION WITH FIXED EFFECTS - DEVELOPED COUNTRIES}

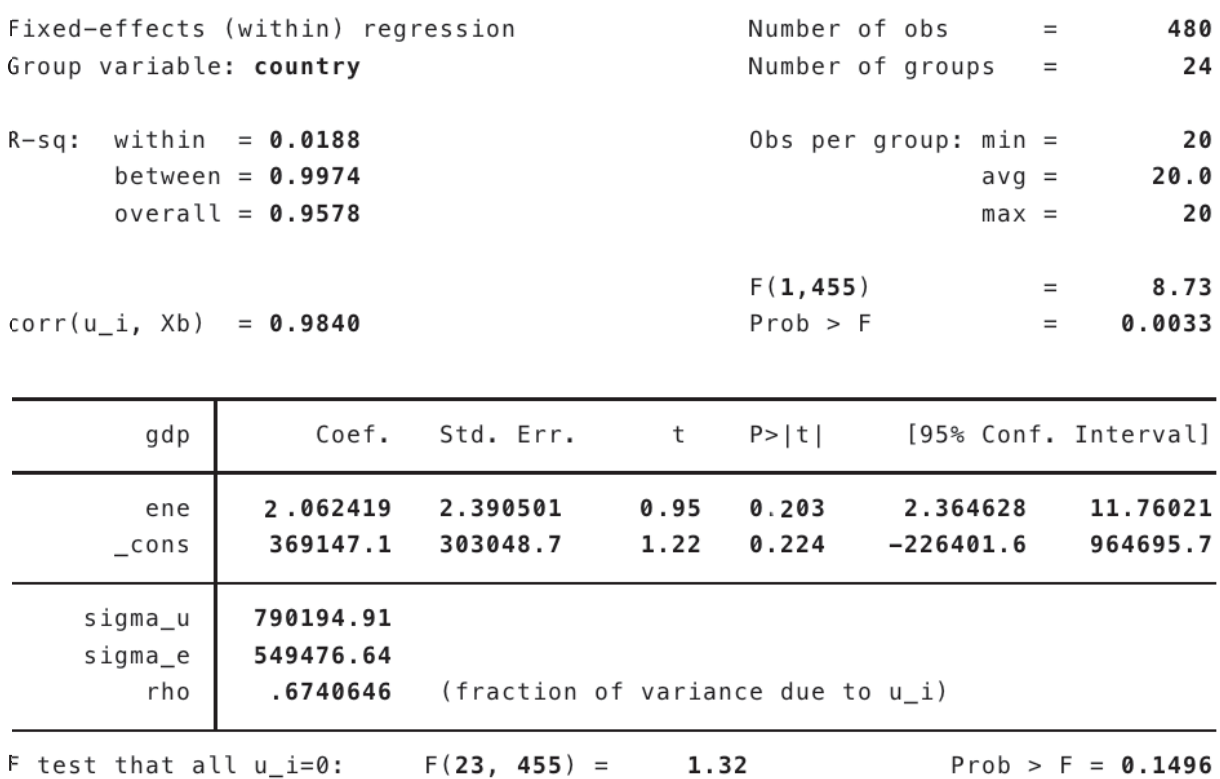

Source: Author's calculation.

From Table 5 we see that the coefficient of 2.062 is for the ene variable, which indicates that if the energy consumption is changed by one unit to the observed variable GDP would change for 2.062 units. If we consider the t-value, we can see that it is smaller than 1.96 , with which we conclude that the variable energy consumption has not a significant influence on the observed variable GDP. P-test confirms the same as the t-test that there is no substantial significance of the ene variable on the observed variable. Using Breusch-Pagan LM test for crosssectional dependence correlation we conclude that we have no cross-sectional dependence. After testing heteroscedasticity, we concluded that there is no presence of heteroskedasticity in the model. 


\section{Conclusion}

From the analysis conducted in this paper, we can conclude that there is a very strong correlation between energy consumption and economic growth. Based on the data examined and the results, we can confirm the original hypothesis in the work of the vast nexus of observed variables. We can also conclude that this association is present in all the monitored countries, regardless of their size and level of development. The data were collected for thirty countries involving the European Union countries and other European countries and their energy consumption, and energy production are distinct and attractive to this work. For GDP, we took data on GDP in all the countries observed in market prices. Total energy consumption is taken for the energy consumption variable, which is obtained by summing the energy consumption of all available energy sources, expressed in equivalent tons of oil. We observed countries that are developed and long-lasting states of the European Union or the transition countries that are less developed and became members of the European Union subsequently. Another problem that we have explored in this article is a comparison of developed and developing or transition countries, and we compared the results. According to some authors, like Ucan and others (2014), the link between energy and economic growth in the short term does not exist in developed countries. However, in the long run, there is a correlation between the observed variables for developed and underdeveloped countries. Based on the results obtained, we can confirm the very high correlation between observed variables for countries in transition. However, in developing countries, there is no correlation between observed variables, most likely because these countries have reached a level of development where energy consumption does not have a major impact on GDP.

There are a few drawbacks in this paper, for example, the number of the surveyed countries should be increased. This paper observed only EU countries and other European countries. We should do research involving all relevant countries in the world and observe them over a longer period. Interesting for future research is the comparability of these two observed variables between countries that are energy independent, producing enough energy from their resources, and those countries that are not. From this research, we should see if there is a difference between these countries or not, or whether there is an advantage to countries that are self-sufficient due to their power sources. In this paper, we didn't want to compare countries that have own energy production with those countries that don't have own energy production. 


\section{Reference:}

Belke. A, Dobnik. F, Dreger. C, (2011). «Energy consumption and economic growth: New insights into the cointegration relationship», Energy Economics, 33, 782-789.

Bildirici. M, (2014). «Relationship between biomass energy and economic growth in transition countries: panel ARDL approach», GBC Bioenergy, 6, 717-726.

Hu. Y, Guo. D, Wang. M, Zhang. X, Wang. S, (2015). «The relationship between energy consumption and economic growth: Evidence from China's industrial sectors», Energies, 8, 9392-9406.

Kasprowicz. R, (2014). «Economic growth and energy consumption in 12 European countries: a panel data approach», Journal of International Studies, 7(3), 112-122.

King. C, (2015). «Comparing World Economic and Net Energy Metrics», Energies, 8, 12997-13020.

Linh. D, Lin. S, (2012). «Co2 Emissions, energy consumption, economic growth and FDI in Vietnam», Managing Global Transitions, 12(3), 219-232.

Mahalik. M, Mallick. H, (2014). «Energy consumption, economic growth, and financial development: Exploring the empirical linkages for India», The Journal of Developing Areas, 48(4), 139-159.

Yang. L, Yang. T, (2015). «Energy consumption and economic growth from perspective of spatial heterogeneity: Statistical analysis based on variable coefficient model», Annals of Operations Research, 228, 151-161.

Ucan. O, Aricioglu. E, Yucel. F, (2014). «Energy consumption and economic growth nexus: Evidence from developed countries in Europe», International Journal of Energy and Policy, 4(3), 411-419. 


\section{Appendix}

Table 3.

\section{ESTIMATED FIXED EFFECTS (USING DUMMIES AND REGRESS)}

\begin{tabular}{|c|c|c|c|c|c|c|}
\hline i. country & - Icountr & $1-32$ & (naturalty & _Icountry_1 & om & tted) \\
\hline Source & SS & $d f$ & MS & Number of obs & $=$ & 640 \\
\hline & & & & $F(32,607)$ & $=$ & 485.61 \\
\hline Model & $3.5190 \mathrm{e}+15$ & 32 & $1.0997 e+14$ & Prob $>F$ & $=$ & 0.0000 \\
\hline Residual & $1.3746 e+14$ & 607 & $2.2646 e+11$ & R-squared & $=$ & 0.9624 \\
\hline & & & & Adj $R$-squared & $=$ & 0.9604 \\
\hline Total & $3.6565 e+15$ & 639 & $5.7222 e+12$ & Root MSE & $=$ & $4.8 e+05$ \\
\hline
\end{tabular}

\begin{tabular}{|c|c|c|c|c|c|c|}
\hline$g d p$ & Coef. & Std. Err. & $\mathrm{t}$ & $P>|t|$ & [95\% Conf. & Interval] \\
\hline ene & 7.023809 & 2.067795 & 3.40 & 0.001 & 2.962908 & 11.08471 \\
\hline _Icountry_2 & -521039.9 & 714819.6 & -0.73 & 0.466 & -1924860 & 882779.9 \\
\hline -Icountry_3 & -3036798 & 2284934 & -1.33 & 0.184 & -7524134 & 1450539 \\
\hline _Icountry_4 & -3130851 & 2339991 & $-1 \cdot 34$ & 0.181 & -7726312 & 1464611 \\
\hline _Icountry_5 & -3156288 & 2308197 & -1.37 & 0.172 & -7689310 & 1376733 \\
\hline _Icountry_6 & -2987353 & 2329142 & -1.28 & 0.200 & -7561508 & 1586802 \\
\hline _Icountry_7 & -2275528 & 1908504 & -1.19 & 0.234 & -6023600 & 1472543 \\
\hline _Icountry_8 & -3096395 & 2354309 & $-1 \cdot 32$ & 0.189 & -7719976 & 1527186 \\
\hline _Icountry_9 & -3023926 & 2337323 & -1.29 & 0.196 & -7614148 & 1566295 \\
\hline _Icountry_10 & -3042651 & 2321068 & $-1 \cdot 31$ & 0.190 & -7600949 & 1515648 \\
\hline _Icountry_11 & -2831547 & 2187604 & -1.29 & 0.196 & -7127739 & 1464645 \\
\hline _Icountry_12 & -2441884 & 2044182 & -1.19 & 0.233 & -6456413 & 1572645 \\
\hline _Icountry_13 & -3100033 & 2346518 & -1.32 & 0.187 & -7708312 & 1508245 \\
\hline _Icountry_14 & -2569813 & 2101309 & -1.22 & 0.222 & -6696532 & 1556906 \\
\hline _Icountry_15 & -3085704 & 2356504 & $-1 \cdot 31$ & 0.191 & -7713594 & 1542186 \\
\hline _Icountry_16 & -3100761 & 2352131 & $-1 \cdot 32$ & 0.188 & -7720063 & 1518542 \\
\hline _Icountry_17 & -3098893 & 2350716 & $-1 \cdot 32$ & 0.188 & -7715416 & 1517630 \\
\hline _Icountry_18 & -3084567 & 2352047 & $-1 \cdot 31$ & 0.190 & -7703705 & 1534571 \\
\hline _Icountry_19 & -3127420 & 2325893 & $-1 \cdot 34$ & 0.179 & -7695194 & 1440353 \\
\hline _Icountry_20 & -3085707 & 2359148 & $-1 \cdot 31$ & 0.191 & -7718790 & 1547376 \\
\hline _Icountry_21 & -2931388 & 2251237 & -1.30 & 0.193 & -7352547 & 1489770 \\
\hline _Icountry_22 & -3016777 & 2306888 & $-1 \cdot 31$ & 0.191 & -7547228 & 1513673 \\
\hline _Icountry_23 & -3263444 & 2234284 & -1.46 & 0.145 & -7651310 & 1124421 \\
\hline _Icountry_24 & -3061694 & 2324419 & -1.32 & 0.188 & -7626574 & 1503187 \\
\hline _Icountry_25 & -3175186 & 2309937 & $-1 \cdot 37$ & 0.170 & -7711626 & 1361253 \\
\hline _Icountry_26 & -3092432 & 2350351 & $-1 \cdot 32$ & 0.189 & -7708239 & 1523376 \\
\hline -Icountry_27 & -3122607 & 2337203 & $-1 \cdot 34$ & 0.182 & -7712592 & 1467378 \\
\hline _Icountry_28 & -3102261 & 2308891 & $-1 \cdot 34$ & 0.180 & -7636646 & 1432124 \\
\hline _Icountry_29 & -3008804 & 2290484 & $-1 \cdot 31$ & 0.189 & -7507039 & 1489431 \\
\hline _Icountry_30 & -2413150 & 2058973 & -1.17 & 0.242 & -6456725 & 1630425 \\
\hline _Icountry_31 & -3092944 & 2355592 & -1.31 & 0.190 & -7719045 & 1533156 \\
\hline _Icountry_32 & -2969766 & 2322185 & -1.28 & 0.201 & -7530258 & 1590726 \\
\hline -cons & 3087794 & 2357676 & 1.31 & 0.191 & -1542397 & 7717986 \\
\hline
\end{tabular}

Source: Author's calculation. 
Table 4.

THE LEAST SQUARE DUMMY VARIABLE MODEL (LSDV)

\begin{tabular}{|c|c|c|}
\hline Variable & ols & ols_dum \\
\hline ene & $9.9553498 * * *$ & $7.0238087 * * *$ \\
\hline Icountry_2 & & -521039.88 \\
\hline _Icountry_3 & & -3036797.6 \\
\hline _Icountry_4 & & -3130850.6 \\
\hline Icountry_5 & & -3156288.4 \\
\hline _Icountry_6 & & -2987353.1 \\
\hline Icountry_7 & & -2275528.5 \\
\hline Icountry_8 & & -3096395 \\
\hline _Icountry_9 & & -3023926.5 \\
\hline Icountry_10 & & -3042650.6 \\
\hline _Icountry_11 & & -2831547.2 \\
\hline Icountry_12 & & -2441884 \\
\hline Icountry_13 & & -3100033.2 \\
\hline _Icountry_14 & & -2569813.1 \\
\hline Icountry_15 & & -3085704 \\
\hline -Icountry_16 & & -3100760.6 \\
\hline -Icountry_17 & & -3098892.7 \\
\hline Icountry_18 & & -3084567.4 \\
\hline _Icountry_19 & & -3127420.3 \\
\hline Icountry_20 & & -3085707 \\
\hline _Icountry_21 & & -2931388.4 \\
\hline _Icountry_22 & & -3016777.5 \\
\hline _Icountry_23 & & -3263444.4 \\
\hline _Icountry_24 & & -3061693.9 \\
\hline _Icountry_25 & & -3175186.5 \\
\hline _Icountry_26 & & -3092431.5 \\
\hline _Icountry_27 & & -3122607.2 \\
\hline _Icountry_28 & & -3102261.4 \\
\hline _Icountry_29 & & -3008803.6 \\
\hline _Icountry_30 & & -2413150.4 \\
\hline _Icountry_31 & & -3092944.5 \\
\hline _Icountry_32 & & -2969766.1 \\
\hline$-\operatorname{cons}$ & -10156.686 & 3087794.1 \\
\hline $\mathrm{N}$ & 640 & 640 \\
\hline
\end{tabular}

Source: Author's calculation. 
Table 5.

\section{PANEL DATA FIXED EFFECTS: COMMON INTERCEPT AND N-1 BINARY REGRESSORS}

\begin{tabular}{r|crc} 
Source & SS & $\mathrm{df}$ & MS \\
\hline $\begin{array}{r}\text { Model } \\
\text { Residual }\end{array}$ & $3.5190 \mathrm{e}+15$ & 32 & $1.0997 \mathrm{e}+14$ \\
\hline Total & $3.6565 \mathrm{e}+15$ & 639 & $5.7222 \mathrm{e}+12$
\end{tabular}

$$
\begin{array}{llr}
\text { Number of obs } & = & 640 \\
\mathrm{~F}(32, \quad 607) & = & 485.61 \\
\text { Prob }>\mathrm{F} & = & 0.0000 \\
\text { R-squared } & =0.9624 \\
\text { Adj R-squared } & =0.9604 \\
\text { Root MSE } & =4.8 \mathrm{e}+05
\end{array}
$$

\begin{tabular}{|c|c|c|c|c|c|c|}
\hline$g d p$ & Coef. & Std. Err. & $\mathrm{t}$ & $P>|t|$ & [95\% Conf. & Interval] \\
\hline ene & 7.023809 & 2.067795 & 3.40 & 0.001 & 2.962908 & 11.08471 \\
\hline _Icountry_2 & -521039.9 & 714819.6 & -0.73 & 0.466 & -1924860 & 882779.9 \\
\hline _Icountry_3 & -3036798 & 2284934 & -1.33 & 0.184 & -7524134 & 1450539 \\
\hline _Icountry_4 & -3130851 & 2339991 & -1.34 & 0.181 & -7726312 & 1464611 \\
\hline _Icountry_5 & -3156288 & 2308197 & -1.37 & 0.172 & -7689310 & 1376733 \\
\hline _Icountry_6 & -2987353 & 2329142 & -1.28 & 0.200 & -7561508 & 1586802 \\
\hline _Icountry_7 & -2275528 & 1908504 & -1.19 & 0.234 & -6023600 & 1472543 \\
\hline _Icountry_8 & -3096395 & 2354309 & -1.32 & 0.189 & -7719976 & 1527186 \\
\hline _Icountry_9 & -3023926 & 2337323 & -1.29 & 0.196 & -7614148 & 1566295 \\
\hline _Icountry_10 & -3042651 & 2321068 & -1.31 & 0.190 & -7600949 & 1515648 \\
\hline _Icountry_11 & -2831547 & 2187604 & -1.29 & 0.196 & -7127739 & 1464645 \\
\hline _Icountry_12 & -2441884 & 2044182 & -1.19 & 0.233 & -6456413 & 1572645 \\
\hline _Icountry_13 & -3100033 & 2346518 & -1.32 & 0.187 & -7708312 & 1508245 \\
\hline _Icountry_14 & -2569813 & 2101309 & -1.22 & 0.222 & -6696532 & 1556906 \\
\hline _Icountry_15 & -3085704 & 2356504 & -1.31 & 0.191 & -7713594 & 1542186 \\
\hline _Icountry_16 & -3100761 & 2352131 & -1.32 & 0.188 & -7720063 & 1518542 \\
\hline _Icountry_17 & -3098893 & 2350716 & -1.32 & 0.188 & -7715416 & 1517630 \\
\hline _Icountry_18 & -3084567 & 2352047 & -1.31 & 0.190 & -7703705 & 1534571 \\
\hline _Icountry_19 & -3127420 & 2325893 & -1.34 & 0.179 & -7695194 & 1440353 \\
\hline _Icountry_20 & -3085707 & 2359148 & -1.31 & 0.191 & -7718790 & 1547376 \\
\hline _Icountry_21 & -2931388 & 2251237 & -1.30 & 0.193 & -7352547 & 1489770 \\
\hline _Icountry_22 & -3016777 & 2306888 & -1.31 & 0.191 & -7547228 & 1513673 \\
\hline _Icountry_23 & -3263444 & 2234284 & -1.46 & 0.145 & -7651310 & 1124421 \\
\hline _Icountry_24 & -3061694 & 2324419 & -1.32 & 0.188 & -7626574 & 1503187 \\
\hline _Icountry_25 & -3175186 & 2309937 & -1.37 & 0.170 & -7711626 & 1361253 \\
\hline _Icountry_26 & -3092432 & 2350351 & -1.32 & 0.189 & -7708239 & 1523376 \\
\hline _Icountry_27 & -3122607 & 2337203 & -1.34 & 0.182 & -7712592 & 1467378 \\
\hline _Icountry_28 & -3102261 & 2308891 & -1.34 & 0.180 & -7636646 & 1432124 \\
\hline _Icountry_29 & -3008804 & 2290484 & -1.31 & 0.189 & -7507039 & 1489431 \\
\hline _Icountry_30 & -2413150 & 2058973 & -1.17 & 0.242 & -6456725 & 1630425 \\
\hline _Icountry_31 & -3092944 & 2355592 & -1.31 & 0.190 & -7719045 & 1533156 \\
\hline _Icountry_32 & -2969766 & 2322185 & -1.28 & 0.201 & -7530258 & 1590726 \\
\hline _cons & 3087794 & 2357676 & 1.31 & 0.191 & -1542397 & 7717986 \\
\hline
\end{tabular}

Source: Author's calculation. 


\title{
POVEZANOST IZMEĐU POTROŠNJE ENERGIJE I EKONOMSKOG RASTA ZA 30 ZEMALJA EUROPE - PANEL
}

\begin{abstract}
Sažetak
U ovom radu proučavamo povezanost između potrošnje energije i ekonomskog rasta za trideset promatranih zemalja u Europi. Iako postoji mnogo radova na ovu temu, razlika je između njih i ovoga rada u tome što se u ovom radu proučavaju zemlje koje do sada nisu zajedno proučavane. Varijabla koja se koristi za potrošnju energije je finalna potrošnja energije u koju ulaze potrošnje iz svih oblika energije. Koristi se panel analiza koja proučava povezanost na temelju metode fiksnog efekta. Podaci koji se koriste su prikupljeni iz Europske baze podataka Eurostat. Na temelju rezultata panel data regresije možemo zaključiti da postoji velika povezanost između promatranih varijabli. Ono što je potrebno u daljnjem istraživanju je proučiti povezanost varijabli i u dugom i kratkom roku. Isto tako potrebno bi bilo i proučiti da li postoji povezanost između promatranih varijabli za razvijene i nerazvijene zemlje odnosno da li među njima postoji razlika. Jednako zanimljivo bi bilo i proučiti način povezanosti kod zemalja koje imaju vlastite izvore energije i onih koje to nemaju.

Ključne riječi: potrošnja energije, regresija panel podataka, fiksni efekt, bdp.
\end{abstract}

